\title{
New Bioactive Metabolites Produced by Phomopsis cassiae, an Endophytic Fungus in Cassia spectabilis
}

\section{Geraldo H. Silva ${ }^{a}$, Helder L. Teles ${ }^{a}$,Henrique C. Trevisan ${ }^{a}$, Vanderlan da S. Bolzani ${ }^{a}$, Maria C. M. Young , Ludwig H. Pfenning ${ }^{c}$, Marcos N. Eberlin ${ }^{d}$, Renato Haddad ${ }^{\text {, }}$ Claudio M. Costa-Neto and Ângela R. Araújo ${ }^{*}, a$}

\author{
${ }^{a}$ Instituto de Química, Universidade Estadual Paulista, CP 355, 14801-970 Araraquara-SP, Brazil \\ ${ }^{c}$ Departamento de Fitopatologia, Universidade Federal de Lavras, CP 37, 37200-000 Lavras-MG, Brazil \\ ${ }^{d}$ Instituto de Química, Universidade Estadual de Campinas, CP 6154, 13083-970 Campinas-SP, Brazil \\ ${ }^{b}$ Seção de Fisiologia e Bioquímica de Plantas, Instituto de Botânica, CP 4005, 97010-051 São Paulo-SP, Brazil \\ ${ }^{e}$ Departamento de Bioquímica e Imunologia, Faculdade de Medicina de Ribeirão Preto, Universidade de São Paulo, \\ 14049-900 Ribeirão Preto-SP, Brazil
}

\begin{abstract}
Dois novos metabólitos, 2,4-diidroxi-5,6-dimetil benzoato de etila (1) e phomopsilactona (2) foram isolados de Phomopsis cassiae, um fungo endofítico de Cassia spectabilis. As estruturas destes compostos foram elucidadas por dados espectrométricos de 1D e 2D RMN, EM e IV. As substâncias 1 e 2 exibiram forte atividade antifúngica contra os fungos fitopatogênicos Cladosporium cladosporioides e C. sphaerospermum, bem como citotoxidade contra a linhagem celular de tumor cervical humano (HeLa), em experimentos in vitro.
\end{abstract}

Two new metabolites, ethyl 2,4-dihydroxy-5,6-dimethylbenzoate (1) and phomopsilactone (2) were isolated from Phomopsis cassiae, an endophytic fungus in Cassia spectabilis. Their structures were elucidated by 1D and 2D NMR, MS and IR spectral data. Compounds $\mathbf{1}$ and $\mathbf{2}$ displayed strong antifungal activity against the phytopatogenic fungi Cladosporium cladosporioides and C. sphaerospermum, as well as cytotoxicity against human cervical tumor cell line (HeLa), in in vitro assays.

Keywords: endophytic fungi, Phomopsis cassiae, Cassia spectabilis, cytotoxic metabolites, antifungal activity

\section{Introduction}

The genus Cassia, comprising about 600 species widely distributed worldwide, is well known for its diverse biological and pharmacological properties. ${ }^{1}$ Cassia spectabilis ( $\sin$ Senna spectabilis) (DC) Irwin et Barn (Leguminosae) has been used in traditional Brazilian medicine for the treatment of flu and cold, as laxative and purgative. ${ }^{2}$ This observation prompted us to launch a program aiming to search novel bioactive metabolites from cultures of endophytes colonized inside $C$. spectabilis. Leaves of $C$. spectabilis were submitted to isolation of endophytic fungi and seven isolates were obtained, preserved and cultivated on liquid medium to get their crude extracts. The strain Phomopsis cassiae was selected for chemical and biological investigation because of the

* e-mail: araujoar@iq.unesp.br strong antifungal activity against the phytopatogenic fungi Cladosporium sphaerospermum and C. cladosporioides.

Fractionation of the crude EtOAc extract by flash chromatography column on reversed-phase $\mathrm{C}-18$ silica, followed by reversed-phase HPLC, afforded compounds 1-2 and 2-hydroxyphenylacetic acid (3). The structures of the new metabolites, ethyl 2,4-dihydroxy-5,6-dimethyl benzoate (1) and phomopsilactone (2) were determined by analysis of NMR and MS data.

\section{Results and Discussion}

Compound $\mathbf{1}$ was isolated as a white amorphous solid and its molecular formula $\mathrm{C}_{11} \mathrm{H}_{14} \mathrm{O}_{4}$ was deduced from ${ }^{13} \mathrm{C}$ NMR and ESI-MS data $\left[(\mathrm{M}+\mathrm{H})^{+}\right.$at $\left.m / z 211\right]$. This formula displayed five degrees of unsaturation. The ${ }^{1} \mathrm{H},{ }^{13} \mathrm{C}$ NMR 
(Table 1) and DEPT results for $\mathbf{1}$ suggested one phenyl group (five quaternaries carbons), an ester group, a $-\mathrm{CH}_{2} \mathrm{CH}_{3}$ moiety and two aromatic methyls. The ester moiety was in agreement with its absorption at $1633 \mathrm{~cm}^{-1}$ in IR, and the signal at $\delta_{\mathrm{C}}$ 169.2. The DEPT results indicated two exchangeable protons, which were assigned to phenolic hydroxyls. The $\mathrm{FeCl}_{3}$ positive reaction and the IR absorption at $3435 \mathrm{~cm}^{-1}$ confirmed phenolic hydroxyl groups consistent with the singlet at $\delta_{\mathrm{H}-3} 6.26\left(\delta_{\mathrm{C}} 99.9\right)$, indicating an aromatic hydrogen ortho-ortho dihydroxylated. The correlation in the COSY spectrum between $\mathrm{H}-$ $11 \delta_{\mathrm{H}} 1.26(\mathrm{t}, J 7.0 \mathrm{~Hz})$ and $\mathrm{H}-10 \delta_{\mathrm{H}} 4.22(\mathrm{q}, J 7.0 \mathrm{~Hz})$ evidenced an ethyl radical, and the heteronuclear correlation ${ }^{3} J_{\mathrm{CH}}$ between $\delta_{\mathrm{H}} 4.22(\mathrm{H}-10)$ and $\delta_{\mathrm{C}} 169.2(\mathrm{C}-7)$ confirmed the presence of an ethyl ester.

The complete attribution of the hydrogen and carbon peaks was accomplished based on the data of 2D NMR ( $g \mathrm{HMQC}, g \mathrm{HMBC}$, NOESY, $g \mathrm{COSY}$ ). In the $g \mathrm{HMBC}$ spectrum of $\mathbf{1}$, correlation of $\mathrm{H}-3$ with $\mathrm{C}-1$ and $\mathrm{C}-5$, and H-9 with C-4 and C-6 allowed to assign the other substituents in the aromatic ring. In the NOESY spectrum of $\mathbf{1}$, a correlation between $\delta_{\mathrm{H}} 2.10(\mathrm{H}-8)$ and $\delta_{\mathrm{H}} 1.95(\mathrm{H}-9)$, confirmed the proximity of these methyls. Based on these data, the structure of $\mathbf{1}$ was established. This compound was previously published as a synthetic intermediate ${ }^{3-5}$ and, to our knowledge, is being reported at first time as a natural product along with its 1D and 2D NMR data.

Compound 2 was isolated as an yellow solid and it was assigned the molecular formula $\mathrm{C}_{13} \mathrm{H}_{12} \mathrm{O}_{5}$ (eight insaturation degrees) based on HRESIMS $[\mathrm{M}+\mathrm{H}]^{+}$at $\mathrm{m} / \mathrm{z}$ 249.0923], ${ }^{13} \mathrm{C}$ NMR and DEPT data. The ${ }^{1} \mathrm{H}$ NMR spectrum (Table 1) of $\mathbf{2}$ showed two methyl resonances at $\delta_{\mathrm{H}} 1.42$ (d, $J 7.0 \mathrm{~Hz}, 3 \mathrm{H})$ and $1.97(\mathrm{~s}, 3 \mathrm{H})$, two vinilic protons at $\delta_{\mathrm{H}}$ $4.68(\mathrm{~s}, 1 \mathrm{H})$ and $\delta_{\mathrm{H}} 4.74(\mathrm{~s}, 1 \mathrm{H})$, an aldehyde at $\delta_{\mathrm{H}} 10.11(\mathrm{~s}$, $1 \mathrm{H})$ and one benzylic methine at $4.51(\mathrm{q}, J 7.0 \mathrm{~Hz}, 1 \mathrm{H})$.<smiles>CCOC(=O)c1c(O)cc(O)c(C)c1C</smiles><smiles>C#Cc1c(O)c(C)c(O)c2c1C(C)C(=C)OC2=O</smiles>

The ${ }^{13} \mathrm{C}$ NMR and DEPT spectra (Table 1) displayed eight $\mathrm{sp}^{2}$ carbons (six attributed to aromatic carbons, two of them bonded to hydroxyls, and two olefinic) and two carbonyls, one assigned to lactone and another to aldehyde.

The substituents in the aromatic ring were positioned by the heteronuclear correlations ${ }^{2} J_{\mathrm{CH}}$ and ${ }^{3} J_{\mathrm{CH}}$ in $g \mathrm{HMBC}$, between H-13/C-4/C-3/C-5 and H-11/C-6/C-5. The upfield observed at $\mathrm{C}-13$ (6.3) is an indicative that this methyl is surrounded by two oxygenated carbons C-3 (166.8) and C-5 (168.5). The hydrogen-bonded phenolic $\mathrm{OH}$ was placed ortho to the lactone substituent, based on its ${ }^{1} \mathrm{H}$ NMR chemical shift. The connectivities between the subunits $\mathrm{CH}_{3} \mathrm{CHC}=\mathrm{CH}_{2}$ and the aromatic ring were deduced from $g \mathrm{HMBC}$ correlations of H-12/C-7/C-8/C-9. The spatial correlations observed in 1D NOESY of H-11 with H-8/ $\mathrm{H}-12$ and $\mathrm{H}-12$ with $\mathrm{H}-11 / \mathrm{H}-10$ aided in the structural confirmation of phomopsilactone (2).

The known substance 2-hydroxyphenylacetic acid (3) was identified by comparison of the physical constants and spectroscopic data with those published in literature. ${ }^{6}$

Phomopsilactone (2) is a new substance that surprisingly contains a $\delta$-methylene lactone subunit analogous to isotoralactone, a metabolite isolated from the plant Cassia obtusifolia. ${ }^{7}$ This polyketide presents sclerotinin skeleton, whose biosynthesis was proposed by Barber et $a l .{ }^{8}$ and Tokoroyama and Kubota. ${ }^{10}$

The antifungal activity of compounds $\mathbf{1 - 3}$ against the phytopatogenic fungi Cladosporium cladosporioides and

Table 1. ${ }^{1} \mathrm{H}$ and ${ }^{13} \mathrm{C}$ NMR (500 and $125 \mathrm{MHz}, \delta$ value, $J$ in $\mathrm{Hz}$ ) spectral data and $g \mathrm{HMBC}$ correlations of $\mathbf{1}^{\mathrm{a}}$ and $\mathbf{2}^{\mathrm{b}}$

\begin{tabular}{|c|c|c|c|c|c|c|}
\hline & & 1 & & & 2 & \\
\hline Position & ${ }^{1} \mathrm{H}$ & ${ }^{13} \mathrm{C}$ & $g \mathrm{HMBC}(\mathrm{H}$ to $\mathrm{C})$ & ${ }^{1} \mathrm{H}$ & ${ }^{13} \mathrm{C}$ & $g \mathrm{HMBC}$ ( $\mathrm{H}$ to $\mathrm{C})$ \\
\hline 1 & & 112.2 & & & 167.8 & \\
\hline 2 & & 154.5 & & & 100.6 & \\
\hline 3 & $6.26(\mathrm{~s})$ & 99.9 & 1,5 & & 166.8 & \\
\hline 4 & & 157.2 & & & 112.4 & \\
\hline 5 & & 113.8 & & & 168.5 & \\
\hline 6 & & 135.9 & & & 110.5 & \\
\hline 7 & & 169.2 & & & 150.9 & \\
\hline 8 & $2.10(\mathrm{~s})$ & 17.1 & $1,5,6$ & $4.51(\mathrm{q} ; 7.0)$ & 33.4 & $7,12,2$ \\
\hline 9 & $1.95(\mathrm{~s})$ & 11.1 & $4,5,6$ & & 157.4 & \\
\hline 10 & $4.22(\mathrm{q} ; 7.0)$ & 60.2 & 7,11 & $4.68(\mathrm{~s}) / 4.74(\mathrm{~s})$ & 97.4 & $9,8 / 9,8$ \\
\hline 11 & $1.26(t ; 7.0)$ & 14.1 & 10 & $10.11(\mathrm{~s})$ & 194.6 & 5,6 \\
\hline 12 & & & & $1.42(\mathrm{~d} ; 7.0)$ & 25.2 & $7,8,9$ \\
\hline 13 & & & & $1.97(\mathrm{~s})$ & 6.3 & $3,4,5$ \\
\hline
\end{tabular}

a in $\mathrm{CD}_{3} \mathrm{OD},{ }^{\mathrm{b}}$ in DMSO- $d_{6}$. 
C. sphaerospermum was evaluated by bioautography $y^{11,12}$ and the detection limit for the compounds $\mathbf{1}$ and $\mathbf{2}$ was 1.0 $\mu \mathrm{g}$, the same as for the positive control nystatin.

Citotoxity of the compounds $\mathbf{1}, \mathbf{2}$ and $\mathbf{3}$ against human cervical tumor cell line (HeLa) were tested using the MTT assay. ${ }^{13}$ Compound 2 exhibited weak cytotoxity $\left(\mathrm{IC}_{50} 200\right.$ $\mu \mathrm{mol} \mathrm{L}-1)$ and 3 a strong cytotoxicity $\left(\mathrm{IC}_{50} 10 \mu \mathrm{mol} \mathrm{L} \mathrm{L}^{-1}\right)$. Cisplatin, a cytotoxic agent, was used as positive control with $\mathrm{IC}_{50} 5 \mu \mathrm{mol} \mathrm{L}{ }^{-1}$.

\section{Experimental}

\section{Instrumental and chromatography materials}

Optical rotations were measured in $\mathrm{MeOH}$ using a Perkin Elmer polarimeter with a sodium lamp at $598 \mathrm{~nm}$ and $25^{\circ} \mathrm{C}$. IR spectra were recorded on a Perkin ElmerFT-IR, using KBr pellets. The NMR spectra were recorded in $\mathrm{CD}_{3} \mathrm{OD}$ and DMSO- $d_{6}$, on a Varian Unit 500 spectrometer at 500 and $125 \mathrm{MHz}$. Mass spectra ESI-MS were obtained on a Fisons Platform VG mass spectrometer at $20 \mathrm{eV}$. For HRESIMS a Q-TOF Autospec-Micromass equipment was used. Column chromatography (CC) was performed over reversed-phase silica gel 230-400 mesh (Merck). TLC was performed using silica gel 60 (>230 mesh) and precoated silica gel $60 \mathrm{PF}_{254}$ (Merck). Spots on TLC were visualized under UV light and by spraying with anisaldehyde- $\mathrm{H}_{2} \mathrm{SO}_{4}$ reagent, followed by heating at $120^{\circ} \mathrm{C}$. Analytical HPLC was performed on a Varian Pro Star 230 using a Phenomenex C-18 column (250 mm x $4.6 \mathrm{~mm}$ ). Preparative HPLC was performed on a Varian Prep-Star 400 system using a Phenomenex C-18 (250 mm x $21.20 \mathrm{~mm}$ ) preparative column.

\section{Plant material}

The leaves of Cassia spectabilis were collected in June 2001 in Araraquara City. The botanical identification was made by Professor Maria Cláudia Marx Young and a voucher specimen (SILVA-193) has been deposited in the Herbarium of the Instituto de Botânica de São Paulo, Brazil.

\section{Fungal isolation}

Phomopsis cassiae was isolated from healthy leaves of Cassia spectabilis as previously reported. ${ }^{14,15}$ The fungus was identified by Dr. Ludwig H. Pfenning and deposited in the fungal herbarium of the Universidade Federal de Lavras, assigned as CML 292. The strain Phomopsis cassiae was subculture in Petri plates containing Potato Dextrose Agar (PDA) and incubated during seven days. After this period, it was inoculated at $25-28{ }^{\circ} \mathrm{C}$ in 28 Erlenmeyer flasks of $500 \mathrm{~mL}$, each containing $200 \mathrm{~mL}$ of Potato Dextrose Broth (PDB). The cultures were incubated at $25{ }^{\circ} \mathrm{C}$ and aerated by agitation on an orbital shaker at $150 \mathrm{rpm}$ for 28 days. Extraction of the filtered fermentation broth (ca. 5.6 L) with ethyl acetate $(3 \times 2.4 \mathrm{~L})$ provided the organic phase, that was dried with $\mathrm{MgSO}_{4}$ and concentrated to yield $277.1 \mathrm{mg}$ of crude extract.

\section{Extraction and isolation}

The crude extract (277.1 mg) was chromatographed by CC using reverse phase silica (Merck LiChroprep ${ }^{\circledR}$ RP-18 25-40 mm; 3 x $15 \mathrm{~cm}$ ) and eluted with $\mathrm{H}_{2} \mathrm{O}: \mathrm{MeOH}(85: 15)$ to $\mathrm{MeOH}(100 \%)$ gradient to afford 12 fractions $(150 \mathrm{~mL}$ each, Fr-1 to Fr-12). The fraction Fr-2 (19.3 mg, $\mathrm{H}_{2} \mathrm{O}: \mathrm{MeOH}$ - 65:35) was purified on a preparative HPLC column (RP -

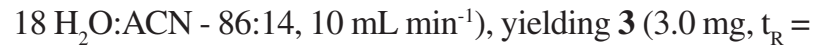
$35 \mathrm{~min}$ ). The fractions Fr-9 (4.0 mg, $\left.\mathrm{H}_{2} \mathrm{O}: \mathrm{MeOH}-35: 65\right)$ and Fr-12 (4.6 mg, $\mathrm{H}_{2} \mathrm{O}: \mathrm{MeOH}$ - 75:25), were analyzed by analytical HPLC $\left[\mathrm{H}_{2} \mathrm{O}: \mathrm{ACN}(35: 5)\right.$ to $\mathrm{ACN}(100 \%)$ gradient, $40 \mathrm{~min}$.] yielding $1\left(4.0 \mathrm{mg}, \mathrm{t}_{\mathrm{R}}=26.3 \mathrm{~min}\right)$ and $2\left(4.6 \mathrm{mg}, \mathrm{t}_{\mathrm{R}}\right.$ $=31.8 \mathrm{~min}$ ).

\section{Antifungal assay}

The microorganisms used in the antifungal assays $C$. cladosporioides (Fresen) de Vries SPG 140 and $C$. sphaerospermum (Penzig) SPC 491, have been maintained at the Instituto de Botânica, São Paulo, Brazil and assays were performed using direct autobiography. ${ }^{11,12}$ Nystatin was used as positive control (detection limit $1 \mu \mathrm{g}$ ).

\section{Cytotoxicity bioassay}

The human cervical cancer cell line (HeLa) assay was performed as previously described. ${ }^{13}$ Cisplatin was used as positive control $\left(\mathrm{IC}_{50} 5.0 \mu \mathrm{mol} \mathrm{\textrm {L } ^ { - 1 }}\right)$.

Ethyl 2,4-dihydroxy-5,6-dimethylbenzoate (1). White solid, $\left(\mathrm{R}_{\mathrm{f}} 0.75\right.$ on $\mathrm{SiO}_{2}-\mathrm{TLC}\left[\mathrm{CHCl}_{3}: \mathrm{MeOH}(9: 1)\right]$; ESI-MS, +20 $\mathrm{eV}, m / z(\%): 211[\mathrm{M}+\mathrm{H}]^{+}(100) ; \mathrm{IR}(\mathrm{KBr}) v_{\max } / \mathrm{cm}^{-1}: 3435$, 2928, 2864, 1633; ${ }^{1} \mathrm{H}$ and ${ }^{13} \mathrm{C}$ NMR spectra (Table 1).

Phomopsilactone (2). Yellow solid, $\mathrm{R}_{\mathrm{f}} 0.58$ on $\mathrm{SiO}_{2}$-TLC [CHCl-MeOH (9:1)]; $\alpha]^{25}+50\left(\mathrm{c} 0.19 \mathrm{CHCl}_{3}\right)$; HRESIMS: $m / z, 249.0923$ (calc. for $\mathrm{C}_{13} \mathrm{H}_{12} \mathrm{O}_{5}, 249.0763$ ); IR (KBr) $v_{\max }$ ' $\mathrm{cm}^{-1}: 3435,2925,2860,1633 ;{ }^{1} \mathrm{H}$ and ${ }^{13} \mathrm{C}$ NMR spectra (Table 1). 


\section{Acknowledgments}

This work was funded by grants of the São Paulo State Research Foundation (FAPESP) within the BiotaFAPESP - The Biodiversity Virtual Institute Program (www.biota.org.br); Grant \# 03/02176-7 awarded to V. da S. B., main investigator. The authors V. S. B and M. C. M. Y. acknowledge CNPq for research fellowships. H. L. T and G. H. S. acknowledge CAPES and CNPq for Ph.D. fellowships.

\section{References}

1. Vilegas, C.J.; Bolzani, V.S.; Furlan, M.; Barreiro, E.; Young, M.C.M.; Tomazela, D.; Eberlin, M.N.; J. Nat. Prod. 2004, 67, 908, and references therein.

2. Lorenzi, H.; Matos, F.J.A.; Plantas Medicinais do Brasil Nativas e Exóticas, Instituto Plantarum: Nova Odessa, 2002, p. 291.

3. Canonica, B.; Rindone, B.; Santaniello, E.; Scolastico, C.; Tetrahedron 1972, 28, 4395.

4. Canonica, B.; Rindone, B.; Santaniello, E.; Scolastico, C.; Tetrahedron Lett. 1971, 28, 2691.

5. Bartlett, A.J.; Holker, J.S.E.; O’ Brien, E.; J. Chem. Soc., Perkin Trans. I 1983, 667.
6. Ballester, A.; Verwey, A.; Overeem, J.C.; Phytochemistry 1975, 14, 1667.

7. Kitanaka, S.; Takido, M.; Phytochemistry 1981, 20, 1951.

8. Barber, J.; Garson, M.J.; Staunton, J.; J. Chem. Soc., Perkin Trans. 1 1981, 9, 2584.

9. Curtis, R.F.; Hassall, C.H. ; Nazar, M.; J. Chem. Soc. (C) 1968 , 85.

10. Toroyama, T.; Kubota, T.; J. Chem. Soc. (C) 1971, 2703.

11. Rhalison, L.; Hamburger, M.; Hostettmann, K.; Monod, M.; Frenk, E.; Phytochem. Anal. 1991, 5, 199.

12. Lopes, M.N.; Oliveira, A.C.; Young, M.C.M.; Bolzani, V.S.; J. Braz. Chem. Soc. 2004, 15, 468.

13. Mosmann, T.; J. Immunol. Methods 1983, 65, 55.

14. Maier, W.; Hammer, K.; Dammann, U.; Schulz, B.; Strack, D.; Planta 1997, 202, 36.

15. Cafêu, M.C.; Silva, G.H.; Teles, H.L.; Bolzani, V.S.; Araújo, A.R.; Young, M. C.M.; Pfenning, L.H.; Quím. Nova, 2005, 28, 991 .

Received: June 14, 2005

Published on the web: October 6, 2005

FAPESP helped in meeting the publication costs of this article. 